\title{
DESAIN SEA SCAPE KAWASAN WISATA “GREEN TURTLE” PANTAI SEDAYU KABUPATEN LOMBOK UTARA
}

\author{
Sitti Hilyana ${ }^{1 *}$, Andre Rachmat Scabra ${ }^{1)}$, Rini Saptaningtyas ${ }^{2)}$ \\ 1) Program Studi Budidaya Perairan, Universitas Mataram \\ 2) Program Studi Teknik Sipil, Universitas Mataram \\ Jalan Majapahit Nomor 62, Mataram 83125 \\ *)alamat korespondensi: sittihilyana@yahoo.com
}

\begin{abstract}
ABSTRAK
Pantai Sedayu Kabupaten Lombok Utara merupakan salah satu lokasi peneluran penyu hijau (green turtle) di Indonesia. Lokasi peneluruan penyu sampai saat ini sangat resisten dari berbagai ancaman seperti penangkapan baby turtle, pengaweta penyu dijadikan sebagai cendera mata kepada wisatawan, pengambilan telur penyu, dan sebagainya. Disamping pengambilan langsung, penangkapan secara tidak langsung juga terjadi akibat terperangkap di jarring nelayan. Permasalahan tersebut segera diatasi melalui upaya konservasi untuk menghindari kepunahan biota yang sangat langka ini. Salah satu metode transfer pengetahuan kepada masyarakat sasaran yang dinilai lebih efektif adalah melakukan pemberdayaan masyarakat pantai Sedayu diarahkan yang diarahkan untuk peningkatan kapasitas masyarakat dalam perlindungan dan pelestarian penyu sekaligus mengembangkan kawasan sebagai destinasi wisata "green turtle". Keluaran yang diharapkan dari kegiatan pengabdian kepada mayarakat ini adalah : Tersusunnya Desain Seascape Pantai Sedayu sebagai Blue Print Pengembangan Wisata "Green Turtle" , Terbangunnya Destinasi Wisata di Kabupaten Lombok Utara, Meningkatnya Pendapatan dan Kapasitas Masyarakat dalam Mengelola Kawasan Wisata, Tumbuhnya kesadaran masyarakat dalam melindungi biota langka dan partisipasi dalam mengelola destinasi wisata. Berkembangnya wisata "green turtle" akan berdampak positif terhadap pelestarian biota penting karena masyarakat dapat terlibat secara aktif dan partisipatif dalam pelestarian sumberdaya langka. Pelesarian sumberdaya dibarengi dengan pengembangan kawasan menjadi destinasi wisata, secara social akan membuka lapangan kerja baru bagi masyarakat sehingga secara ekonomi dapat dijadikan sebagai sumber pendapatan masyarakat sekitar. Pendekatan ini sekaligus merupakan salah satu upaya untuk mendukung program pemerintah daerah dalam meningkatkan 10.000 wirausaha baru di Kabupaten Lombok Utara sesuai program kerja pemerintah yang dituangkan dalam RPJMD kabupaten Lombok Utara 2017-2021.
\end{abstract}

Kata Kunci : konservasi, penyu hijau, green turtle, pantai sedayu. 


\section{PENDAHULUAN}

Penyu hijau (green turtle) merupakan biota langka yang menjadi isu konservasi dunia, dan keberadaan biota langka sangat jarang ditemui di perairan beriklim sedang, tetapi tersebar di wilayah tropis dekat dengan pesisir benua dan sekitar kepulauan. Fisik green turtle memiliki warna kuning kehijauan atau coklat hitam gelap, cangkang berbentuk bulat telur bila dilihat dari atas dan kepalanya relatif kecil dan tumpul, ukuran panjang adalah antara 80 hingga $150 \mathrm{~cm}$ dan beratnya dapat mencapai $132 \mathrm{~kg}$. Perkembangbiakan Usia untuk kematangan seksualnya tidak pasti; Sampai saat ini diperkirakan 45-50 tahun. Green Turtle betina bermigrasi dalam wilayah yang luas, antara kawasan mencari makan dan bertelur, tetapi cenderung untuk mengikuti garis pantai dibandingkan menyeberangi lautan terbuka (WWF, 2015).

Pemerintah Republik

Indonesia melalui SK Menteri Pertanian Nomor 716 /KPTS/UM/10/ 80 dan PP No. 7/1999 tentang Pengawetan Tumbuhan dan Satwa, telah menetapkan bahwa penyu hijau merupakan biota yang dilindungi. Saat ini, penyu hijau merupakan biota langka karena habitat tempat bertelurnya mengalami gangguan, akibat pembangunan yang tidak terkendali. Demikian juga habitat tempat mencari makan seperti terumbu karang dan hamparan lamun terus mengalami degradasi akibat sedimentasi atau pengrusakan oleh manusia.

Pengambilan secara langsung di alam merupakan ancaman serius bagi keberlanjutan kehidupan biota langka ini. Para peneliti memperkirakan setiap tahun sekitar 30.000 penyu hijau ditangkap di Baja, California dan lebih dari 50.000 penyu laut dibunuh di kawasan Asia Tenggara (termasuk di Bali) dan di Pasifik Selatan(WWF, 2003). Di banyak negara, anak-anak penyu ditangkap, diawetkan dan dijual sebagai cendera mata kepada wisatawan. Disamping pengambilan langsung, penangkapan secara tidak langsung terjadi setiap tahun, ribuan penyu hijau terperangkap dalam jaring penangkap. Penyu hijau merupakan reptile dan bernafas dengan paru-paru, sehingga saat gagal mencapai permukaan laut, banyak yang mengalami kematian.

Pantai Sedayu Desa Gondang Kabupaten Lombok Utara merupakan lokasi peneluran penyu hijau di Indonesia. Lokasi peneluruan penyu baik didaratan pulau besar maupun pulau kecil sangat resisten dari berbagai ancaman seperti disebutkan diatas, oleh karena itu tindakan konservasi yang memadai sangat penting dilakukan untuk menghindari kepunahan biota yang sangat langka ini (Adnyana, 2009). Pantai Sedayu merupakan habitat penyu hijau yang dalam satu decade terakhir 
pengambilan telur penyu banyak dilakukan oleh masyarakat akibat rendahnya pengetahuan dan pemahaman masyarakat terhadap perlindungan biota langka, sehingga berimplikasi pada menurunnya populasi penyu di perairan NTB karena penyu tidak mampu melakukan regenerasi akibat tingginya eksploitasi telur penyu oleh masyarakat.

Berdasarkan permasalahan diatas, diperlukan desain pengembangan kawasan, khususnya dalam perspektif sea scape sebagai blue print pengembangan area perlindungan dan pelestarian penyu hijau yang di rancang sebagai kawasan wisata berbasis "green turtle conservation", sehingga secara social akan meningkatkan kesadaran masyarakat dalam melestarikan sumberdaya alam, dan secara ekonomi masyarakat dapat memanfaatkan kawasan wisata sebagai sumber ekonomi melalui pengelolaan destinasi wisata "green turtle". Dengan berkembangnya destinasi wisata "green turtle" akan mendukung program pemerintah dalam mengembangkan model wisata konservasi minat khusus.

Keluaran yang diharapkan dari kegiatan pengabdian kepada mayarakat ini adalah Tersusunnya Desain Seascape Pantai Sedayu sebagai Blue Print Pengembangan Wisata "Green Turtle", Terbangunnya Destinasi Wisata di Kabupaten Lombok Utara, Meningkatnya
Pendapatan dan Kapasitas Masyarakat dalam Mengelola Wisata, Tumbuhnya kesadaran dalam melindungi biota langka dan partisipasi mengelola destinasi wisata serta memantapkan wawasan, sikap mental, dan visi dosen dalam melaksanakan

kegiatan fasilitasi, pendampingan pada masyarakat serta menumbuhkan dan meningkatkan kualifikasi peran dosen dalam pemberdayaan pada masyarakat.

\section{METODE PELAKSANAAN}

Kawasan pesisir Sedayu Desa Gondang Kabupaten Lombok Utara memiliki keindahan bentang alam dan panorama yang sangat indah, sehingga sangat potensial untuk pengembangan wisata. Disamping potensi wisata, Pantai Sedayu juga merupakan habitat penyu hijau (biota langka) dilindungi dan menjadi perhatian internasional. Pengambilan telur penyu dilakukan oleh masyarakat akibat kurangnya pengetahuan dan pemahaman sehingga akan berdampak pada ekspolitasi secara tak terkendali dialam, sehingga diperlukan intervensi pemberdayaan masyarakat.

Dalam mengakselerasi pembangunan kelautan dan perikanan, Pemerintah Daerah melalui berbagai program dan pendekatan yang mudah dilakukan oleh masyarakat dalam rangka mengatasi kepunahan biota penting ini. Salah satu pendekatan yang cukup efektif adalah pemberdayaan masyarakat 
pesisir melalui peningkatan kapasitas masyarakat sekaligus menumbuhkan partisipasi dalam pelestarian dan perlindungan habitat penyu yang didesain sebagai destinasi wisata "green turtle". Berkembangnya wisata di Pantai Sedayu akan berdampak positif terhadap pelestarian biota penting karena masyarakat dapat terlibat secara aktif dalam pelestarian sumberdaya langka. Pelesarian sumberdaya dibarengi pengembangan kawasan menjadi destinasi wisata, secara social akan membuka lapangan kerja baru bagi masyarakat sehingga secara ekonomi dapat dijadikan sebagai sumber pendapatan masyarakat sekitar. Pendekatan ini sekaligus merupakan salah satu upaya untuk mendukung program pemerintah daerah dalam meningkatkan 10.000 wirausaha baru di Kabupaten Lombok Utara sesuai program kerja pemerintah yang dituangkan dalam RPJMD kabupaten Lombok Utara 2017-2021.

Salah satu metode transfer pengetahuan kepada masyarakat yang dinilai efektif adalah membangun kesadaran secara profesional yang dapat diterima oleh masyarakat agar tujuan penyadaran masyarakat pesisir dapat tercapai. Disamping untuk tujuan perlindungan biota langka, pemberdayaan masyarakat pantai Sedayu diarahkan untuk meningkatkan kesadaran tentang pelestarian sumberdaya penyu hijau sekaligus mengembangkan kawasan sebagai destinasi wisata.

Kegiatan pengembangan kawasan sebagai destinasi 'green turtle" merupakan solusi pelestarian dan perlindungan biota langka sekaligus mendukung program pemerintah kabupaten Lombok Utara menciptakan 10.000 wirausaha baru dilakukan dengan menggunakan metode kaji tindak partisipatif aktif (participatory action program) secara aktif sejak persiapan sampai evaluasi kegiatan. Berkembangnya Pantai sedayu sebagai destinasi wisata akan menciptakan berbagai lapangan kerja baru sebagai multiflier effect berkembangnya wisata. Teknik yang diterapkan relative sederhana sehingga kelompok masyarakat dan peserta lain sebagai target atau sasaran program dapat dengan mudah melakukan program pemberdayaan dengan baik dan berhasil guna.

Penentuan lokasi kegiatan dipilih berdasarkan kriteria dan karakteristik kawasan. Sebelum kegiatan dilakukan, diperlukan sosialisasi program kepada masyarakat sasaran. Penyadaran masyarakat tentang perlindungan penyu hijau di alam dan pengembangan kawasan sebagai destinasi wisata 'green turtle' dilakukan melalui pelibatan masyarakat secara aktif dalam perlindungan biota penyu sekaligus pelibatan masyarakat dalam pengembangan destinasi wisata. 
Untuk menunjang hal ini, dilakukan perencanaan dan pengembangan kawasan secara koordinatif dan terintegrasi dengan pihak pemerintah daerah sebagai pemegang otorita dalam tata kelola kawasan serta pelibatan seluruh stakeholders yang berkepentingan.

\section{HASIL DAN PEMBAHASAN}

\section{Pelaksanaan}

kegiatan

pengabdian kepada masyarakat disajikan melalui beberapa Gambar berikut:

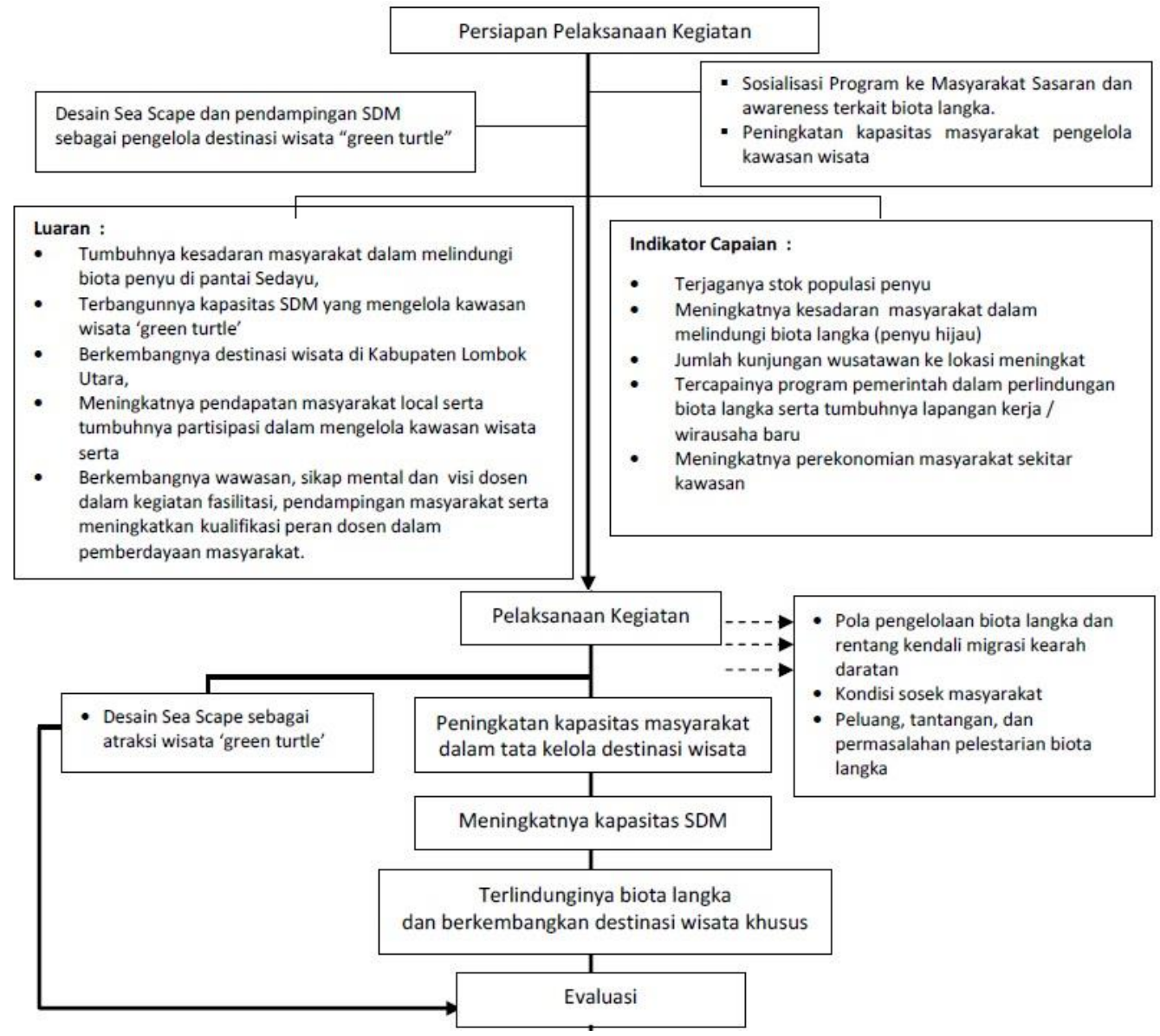

Gambar 1. Tahapan pelaksanaan kegiatan 


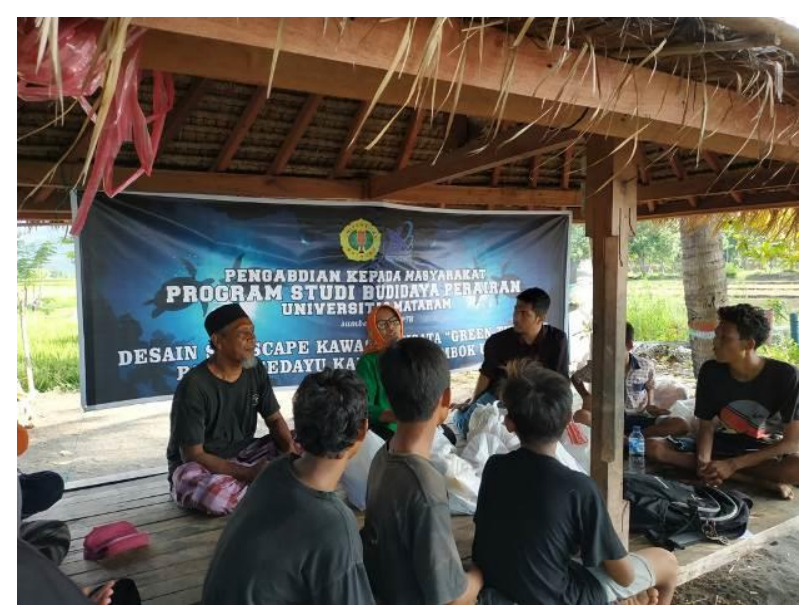

Gambar 2. Tim Pegabdian memberikan materi konservasi penyu hijau

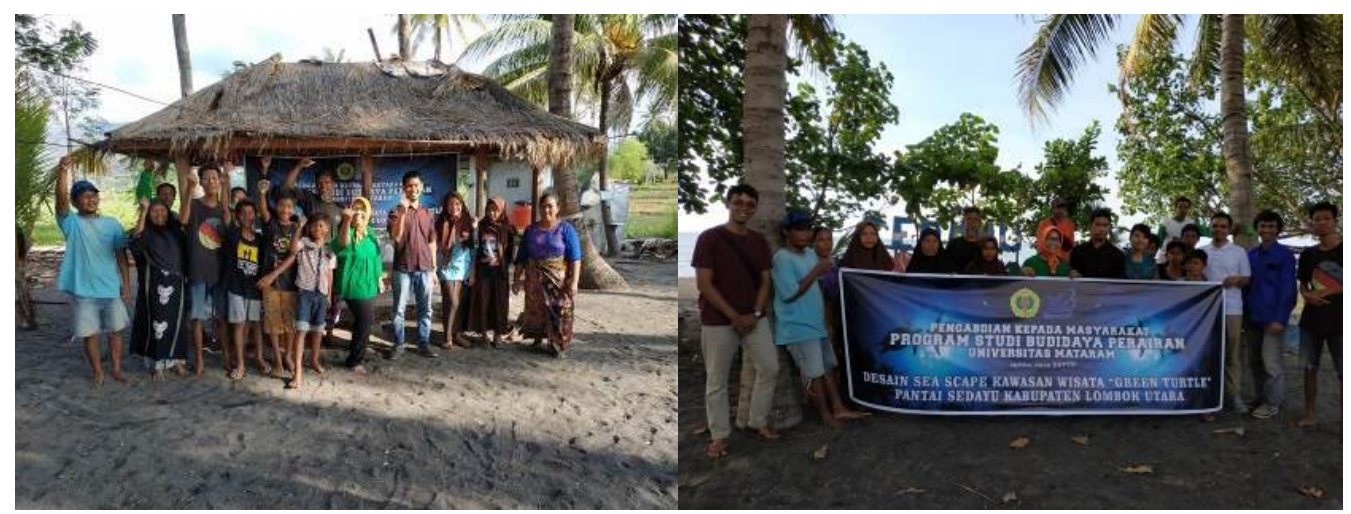

Gambar 3. Sesi foto bersama anggota tim dengan masyarakat pantai Sedayu

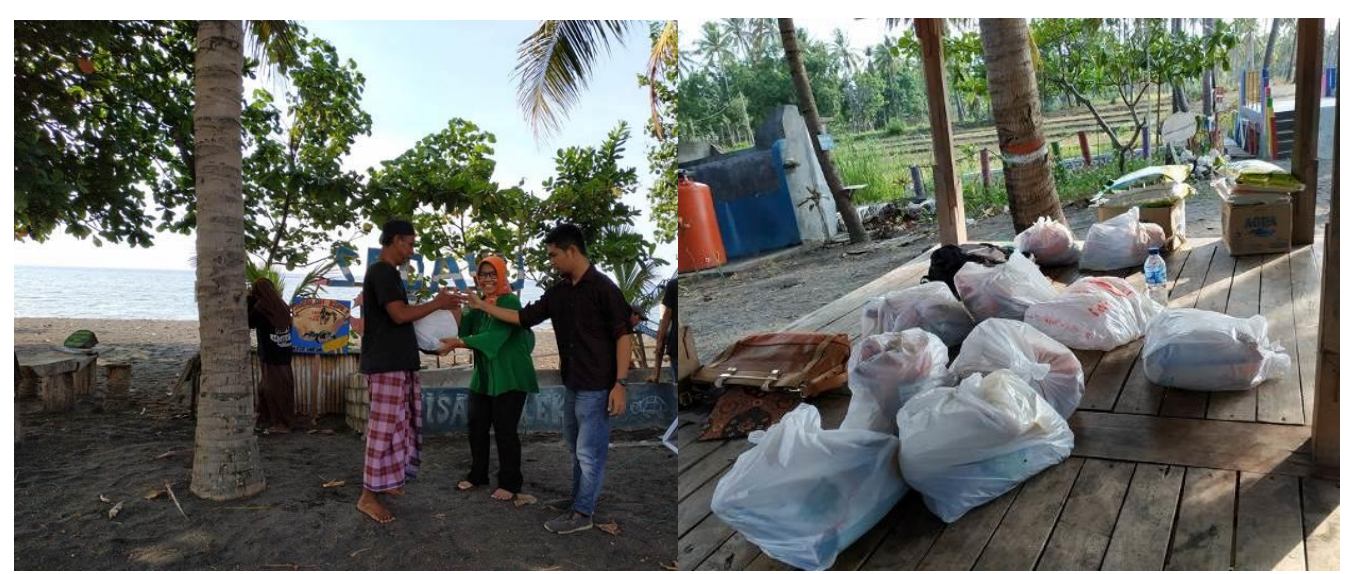

Gambar 4. Bantuan dan Penyerahan bantuan kepada masyarakat pesisir Pantai Sedayu yang menjadi korban bencana gempa 


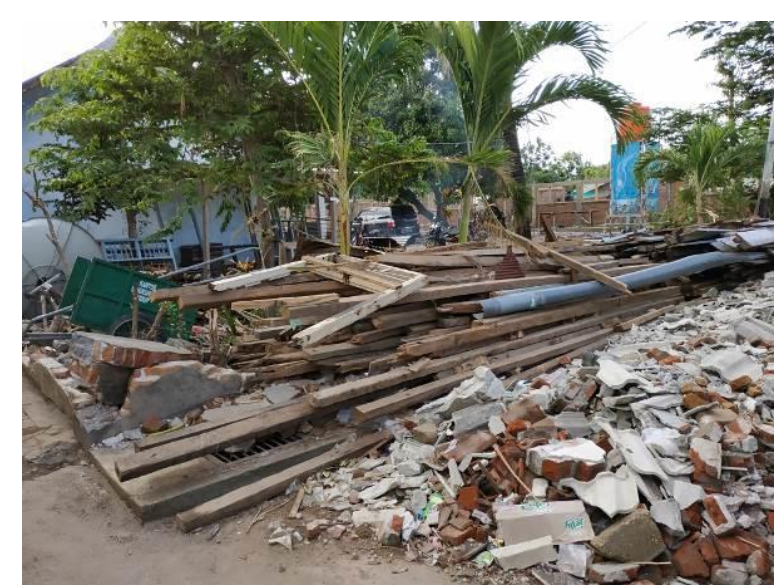

Gambar 5. Kondisi kawasan pesisir Pantai Sedayu pasca bencana gempa

Kegiatan pengabdian kepada masyarakat ini telah dilaksanakan dengan melakukan peyuluhan dan pemberian bantuan berupa bahanbahan kebutuhan pokok masyarakat pantai Sedayu. Penyuluhan tentang pentingnya menjaga keberlanjutan konservasi penyu sangat dibutuhkan oleh masyarakat karena keadaan Pantai Sedayu yang saat ini masih belum stabil akibat bencana Gempa Bumi yang melanda Pulau Lombok, khususnya Kabupaten Lombok Utara. Masyarakat pesisir Patai Sedayu masih mengalami trauma pasca bencana gempa sehingga perhatian terhadap konservasi penyu menjadi berkurang. Penyuluhan yang dilakukan oleh kelompok pengabdian ini diharapkan berhasil menghidupkan kembali semangat dan pandangan masyarakat tentang pentingnya menjaga konservasi penyu untuk kehiduapan yang lebih baik di masa depan. Kelompok pengabdian juga memberikan bantuan berupa kebutuhan pokok kepada masyarakat pesisir yang sampai saat ini masih belum pulih secara total pasca bencana gempa bumi yang melanda.

\section{KESIMPULAN}

Beberapa rekomendasi yang dapat disimpulkan melalui kegiatan pengadian kepada masyarakat ini antara lain;

1. Penatanaan ruang pesisir dan laut Pantai Sedayu.

2. Revitalisasi kawasan yang berfungsi sebagai kawasan wisata penyu untuk menyelamatkan keberadaan penyu, biota dan abiota di perairan, memperbaiki dan melestarikan kualitas lingkungan hidup sekaligus mengamankan kawasan pesisir dari ancaman bencana alam.

3. Penegakan hukum secara tegas bagi perusak habitat penyu.

4. Pengembangan ekonomi masyarakat . 
5. Perbaikan dan peningkatan sarana prasarana serta aksesibilitas .

6. Menjaga dan memelihara kondisi wilayah pesisir yang kondusif melalui pengawasan bersama.

7. Peningkatan peran masyarakat dalam pengelolaan wisata penyu.

\section{DAFTAR PUSTAKA}

Eckert KL, KA Bjorndal, FA Abreu-Grobois, and M.Donnelly (Editors) (1999). Research and Management Techniques for the Conservation of Sea Turtle. IUCN/SSC Marine Turtle Speciallist Group Publication, No 4.

I.B.Windya Adyana, Creusa Hitipew, 2009. Panduan dalam Melakukan
Pemantauan Populasi Penyu di Pantai peneluran di Indonesia. WWF Indonesia dan Universitas Udayana.

Shanker K, B.Pandav, BC. Choudury, 2003. Sea Turtle Conservation : Population Census and Monitoring. A GOI - UNDP Project Manual. Center for Herpetology/madras Crocodile Bank Trust, Mamallapuram, Tamil Nadu India.

Wyneken, J. (2001). The Anatomy of Sea Turtles. U.S. Department of Commerce. NOAA. Technical Memorandum. NMFS - SEFSC 470, 1-172 pp.

WWF, 2002 - 2009. Peta Konservasi Penyu di Indonesia.

WWF, 2010. Panduan Ramah Lingkungan : Pengamatan Penyu. 